\title{
Analysis of Projects undertaken by Quantity Surveyors in Lagos State, Nigeria
}

Aje, Isaac Olaniyi

Department of Quantity Surveying

School of Environmental Technology

Federal University of Technology,

Akure, Nigeria

ajeolaniyi@gmail.com
DOI 10.5592/otmcj.2015.1.5

Research paper

\author{
Adedokun, Olufisayo Adewumi \\ Department of Quantity Surveying \\ School of Environmental Technology \\ Federal University of Technology, \\ Akure, Nigeria \\ fisayoadedokun@gmail.com
}

\author{
Ibironke, Olajide Timothy \\ Department of Quantity Surveying \\ School of Environmental Technology \\ Federal University of Technology, \\ Akure, Nigeria \\ timothyibironke@gmail.com
}

\section{Keywords}

Competencies, Construction, Cost, Projects, Professional, Skills, Quantity Surveyors
INCREASING COST OF CONSTRUCTION WORKS COUPLED WITH INSISTENT COLLAPSE OF BUILDINGS STIMULATED THE INVESTIGATION OF THE SKILLS REQUIRED OF THE QUANTITY SURVEYORS CUM THEIR COMPETENCIES. Due diligence study on the nature of construction projects undertaken were carried out and fifty-eight (58) senior/ associate partners, working in quantity surveying (Qs) firms completed the questionnaires out of Seventy four (74) quantity surveying consultancy firms. Percentile and mean were used for the analysis of data. The study revealed that majority of quantity surveying firms, despite their long years of existence with highly experienced staff members; limit their area of operations to building works, be it low or high rise, thereby leaving out substantial part of their work in both civil and industrial engineering works to be undertaking by others. The study concludes that the management of quantity surveying firms should also delve into civil and industrial engineering works more than before in order to ensure cost effectiveness of these projects. 


\section{INTRODUCTION}

It has long been recognized that the construction industry (where Quantity Surveying Firms operate) is used to regulate the nation's economy apart from the fact that its output constitutes one-half of the gross capital formation and $3-8 \%$ of the Gross Domestic Product (GDP) in most countries (Ameh and Odusami, 2002). Andawei and Nyenke (2001) also posited that construction industry is one of the biggest employers of labour in the country after government at the federal, state and local levels. The construction industry is multidisciplinary in nature (Udeh, 2002). A given project development in the industry requires pooling together of a team whose aim is to actualize a development target. The most important key player in the industry is the client who hires every other person in the team directly or indirectly. The contractor follows along with sub-contractors that carry out the execution of the expert input (in form of presentations and working drawings, specification, bill of quantities etc) into physical reality. There are consultants, comprising the architect who interprets the client's need into a physical structure and environment in form of drawings, perspectives and models to ensure that the client's expectation is assured and the structural engineer who according to Onwusonye (2002) is responsible for structural drawings and details. Services engineers are responsible for electrical and mechanical activities. Depending on complexities of the client's need, there may be specialist acoustic and lighting engineers. Others are project managers, estate surveyors, builders, town planners, environmental analysts and plant engineers in cases of process manufacturing. Then we have the quantity surveyors whose role is that of matching aesthetics and functions against value for money. The quantity surveyor (QS) according to Nigerian Institute of Quantity Surveyors, NIQS (2004) is the expert concerned with financial probity in the conceptualization, planning and execution of development projects both new and refurbishing works. The development costs adviser for building, civil and other engineering projects is Quantity Surveyor.

\section{Literature review}

\section{History of quantity surveyors}

Said, Shafiel and Omran (2014) traced the history and origins of quantity surveyors back to the ancient Egyptian civilization that used dedicated personnel to carry out estimates and costing for their magnificent structures and buildings. It developed into an occupation during the 17 th century restoration of London after the Great Fire. In 1836 the profession entered its new age when the new Houses of Parliament of Great Britain, designed by Sir Charles Barry, became the first major public contract to be fully measured and tendered using detailed bills of quantities for financial accountability (Royal Institution of Chartered Surveyors, RICS, 1998). A quantity surveyor is a professional in the construction industry who has the ability to analyze both cost components and practical physical construction works of a project in a successful way so as to be able to apply the results of his analysis in solving problems peculiar to each project (Nkado, 2000).

\section{The quantity surveyors}

The names given to Quantity surveyors are so enormous all over the world such as cost engineers, building economists, cost managers, construction accountants, etc and different authors have adopted these different names in different studies and in Nigeria (Oke and Ogunsemi, 2009). It is to be noted that the most common name for this professional in Nigeria is “quantity surveyors". Quantity surveyor according to Wikipedia (2014) is

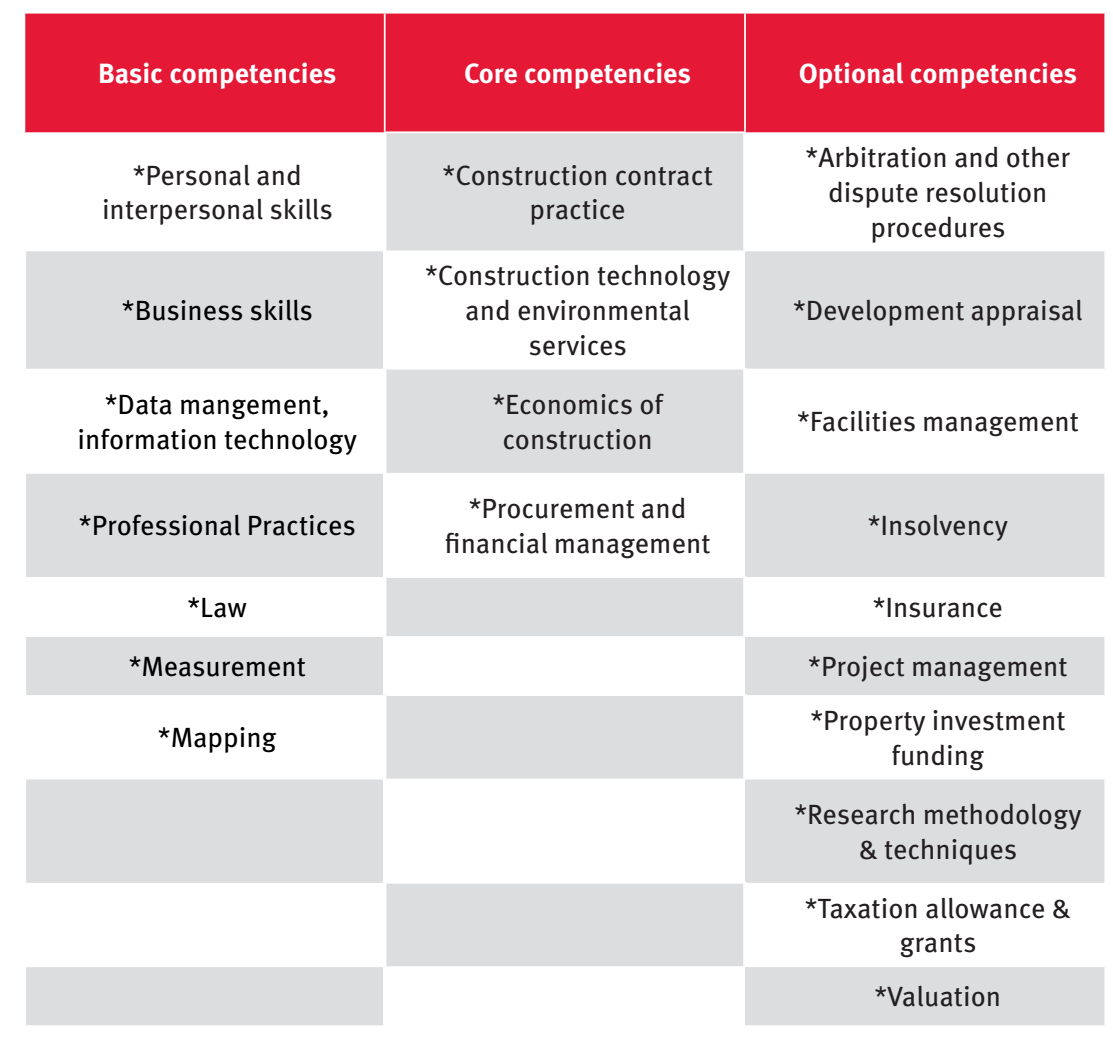

Source: Oke and Ogunsemi (2009)

Table 1: Headings of competencies required by quantity surveyors for APC 


\begin{tabular}{|c|c|c|c|c|c|}
\hline Skill & Mean Ranking & Rank & Basic & Core & Preferred Classification \\
\hline Computer literacy & 3.89 & 1 & $45.2 \%$ & $54.8 \%$ & Core \\
\hline Building Engineering & 3.34 & 2 & $40.4 \%$ & $59.6 \%$ & Core \\
\hline Information Technology & $3 \cdot 33$ & 3 & $64.5 \%$ & $35.5 \%$ & Basic \\
\hline Economics & 3.27 & 4 & $42.7 \%$ & $57.3 \%$ & Core \\
\hline Measurement/Quantification & 3.23 & 5 & $39.8 \%$ & $60.2 \%$ & Core \\
\hline Civil/Heavy Engineering & 3.16 & 6 & $57.6 \%$ & $42.4 \%$ & Basic \\
\hline Professional Practice & 3.15 & 7 & $30.1 \%$ & $69.9 \%$ & Core \\
\hline Construction law & 3.14 & 8 & $40.9 \%$ & $59.1 \%$ & Core \\
\hline Interpersonal skill & 3.11 & 9 & $59.8 \%$ & $40.2 \%$ & Basic \\
\hline Mechanical \& Electrical Service Engineering & 3.10 & 10 & $64.5 \%$ & $35.5 \%$ & Basic \\
\hline Financial skill & 3.10 & 10 & $38.9 \%$ & $61.1 \%$ & Core \\
\hline Leadership skill & 3.09 & 12 & $63.9 \%$ & $36.1 \%$ & Basic \\
\hline Managerial skill & 3.07 & 13 & $60.7 \%$ & $39.3 \%$ & Basic \\
\hline Communication & 3.07 & 13 & $57.7 \%$ & $42.3 \%$ & Basic \\
\hline Marketing/Business skill & 3.01 & 15 & $58.0 \%$ & $42.0 \%$ & Basic \\
\hline Mapping/Surveying & 2.96 & 16 & $59 \cdot 3 \%$ & $40.7 \%$ & Basic \\
\hline Actuarial skill (Knowledge about insurance) & 2.90 & 17 & $59.6 \%$ & $40.4 \%$ & Basic \\
\hline Gas and Petrochemical Engineering & 2.76 & 18 & $73.0 \%$ & $27.0 \%$ & Basic \\
\hline Knowledge about International Trading & 2.71 & 19 & $69.7 \%$ & $30.3 \%$ & Basic \\
\hline Investment analysis & 2.62 & 20 & $77.5 \%$ & $22.5 \%$ & Basic \\
\hline Solid mineral Engineering & 2.60 & 21 & $72.6 \%$ & $27.4 \%$ & Basic \\
\hline
\end{tabular}

Source: Dada and Jagboro (2012)

Table 2: Classification of Skills Required of Quantity Surveyors

"a professional trained, qualified, and experienced in handling construction cost, construction management and construction communication on behalf of the client". The Nigerian Institute of Quantity Surveyors (2004) defined a quantity surveyor as the expert professionally trained and experienced in dealing with construction cost, construction management and construction communication. This expertise he showcases on various types of projects including building construction, civil and structural engineering, mechanical building and engineering services, petrochemicals, mineral extraction, cost and production engineering, environmental economics, planning and urban development, landscaping, interior design and all other relevant areas (Oke and Ogunsemi, 2009; Dada and Jagboro, 2012).
Nkado (2000) in a study conducted defined a quantity surveyor as a professional in the construction industry who has the ability to analyze both cost components and practical physical construction works of a project in a successful way so as to be able to apply the results of his analysis in solving problems peculiar to each project. Nkado (2000) listed the principal services that could be offered by any quantity surveying firm as: preliminary cost advice and feasibility estimates, cost planning, advising on contractual methods, advising on selection of other consultants, advising on contractor selection. Others include preparing tender documents, obtaining or negotiating tenders, reporting on tenders received or package deal/design and build offers, evaluating construction work, preparing and agreeing accounts for/with contractors, preparing expenditure statements for tax accounting purposes, periodic financial reporting, technical auditing, assessing replacement value for insurance, project management related services, giving expert evidence in arbitrations, adjudications and legal disputes, preparing/ defending against construction contract claims (Nkado, 2000).

The ability of quantity surveyor to analyze cost components of a construction project in a scientific way and apply the results of his analysis to a variety of financial and economic problems confronting the developer and the designer metamorphosed quantity surveying from being a trade-based vocation which had developed into a full-fledged profession that is widely accepted in the construction industry.

Dada and Jagboro (2012) in research 

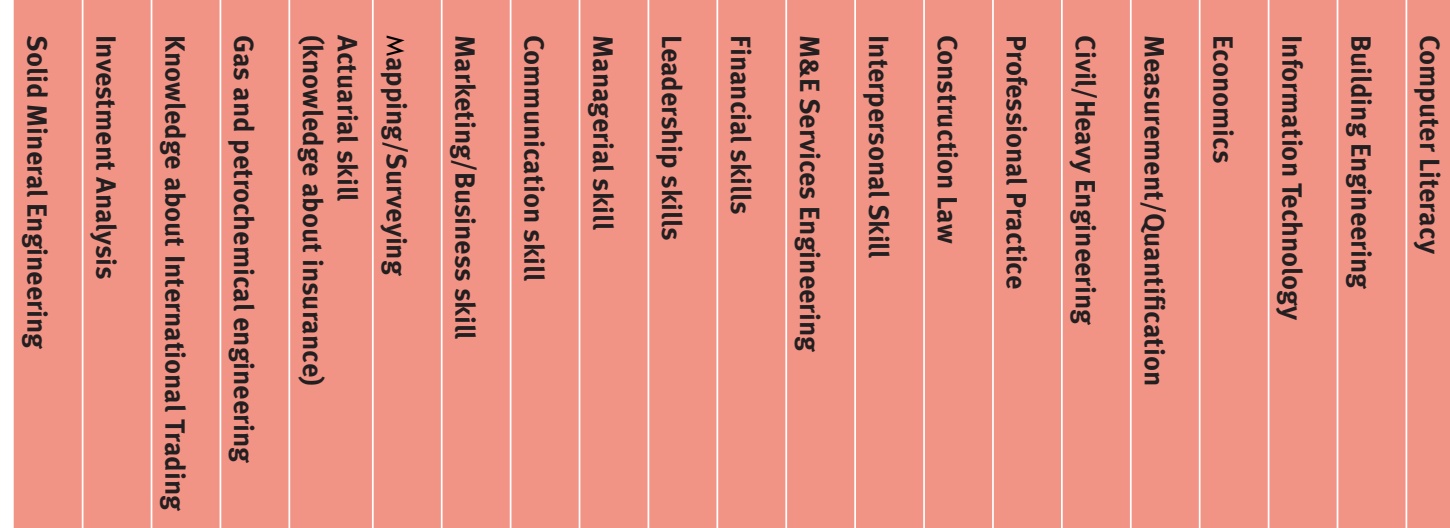

$\stackrel{\underline{\underline{\underline{\underline{m}}}}}{\underline{\underline{n}}}$

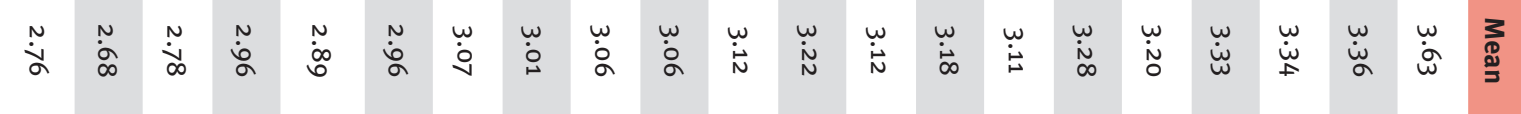

م

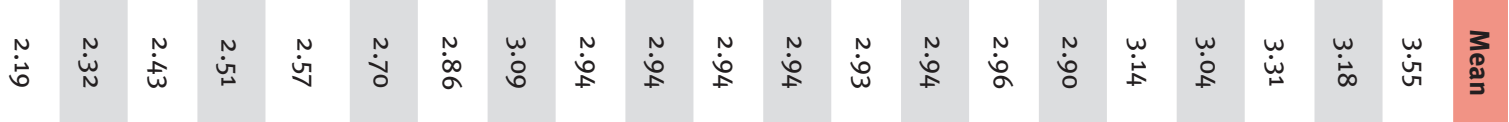

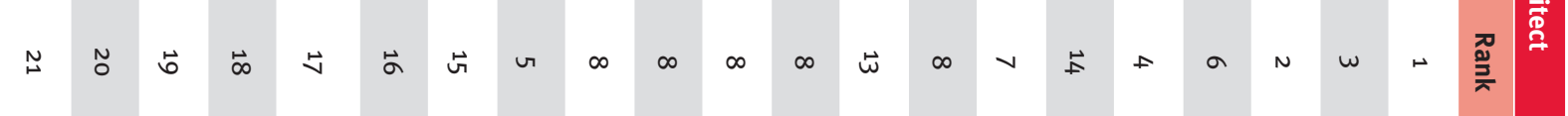

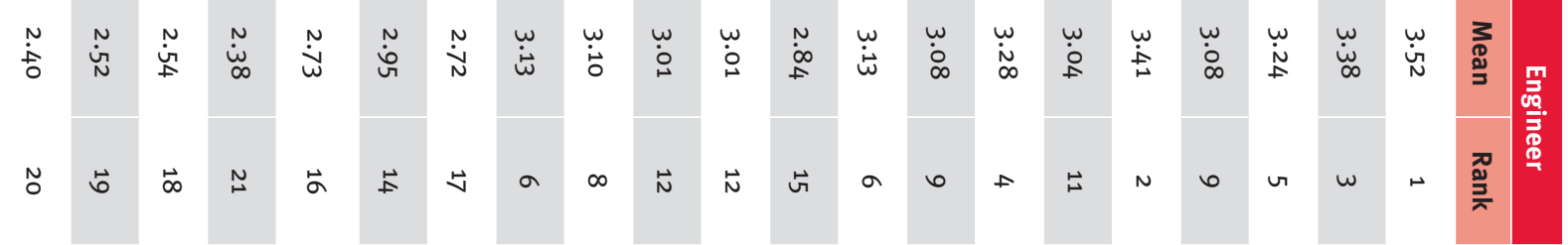

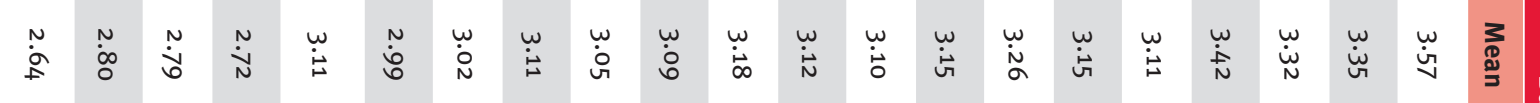

N

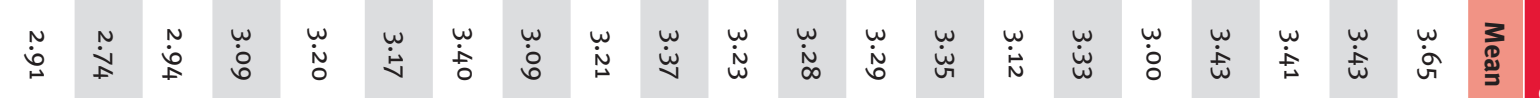

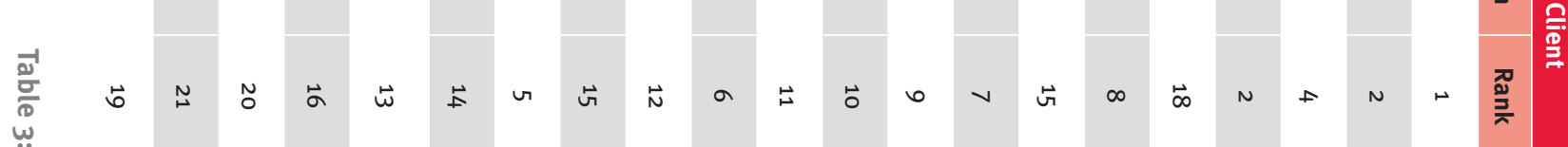

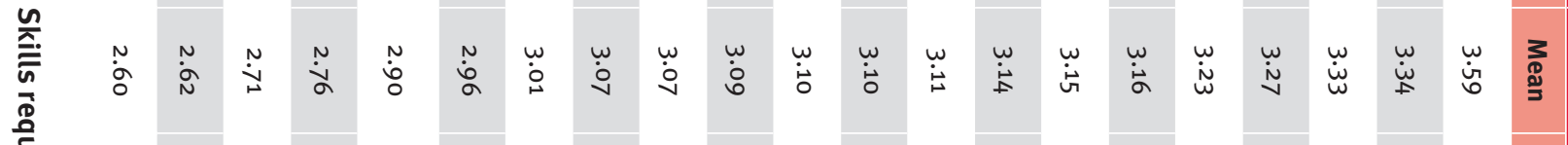

变

m

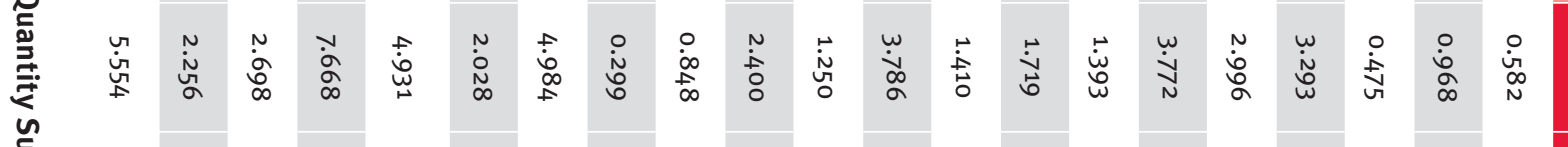

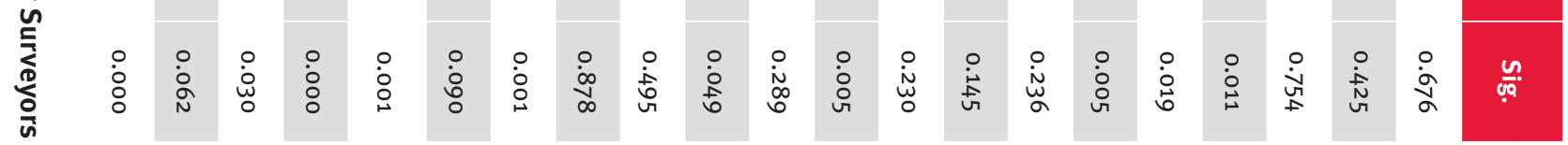




\begin{tabular}{|c|c|c|c|c|}
\hline Nature of projects & \multicolumn{2}{|c|}{ Size $(\mathrm{Nr}) \quad$ Midpoint } & Frequency & \multirow{2}{*}{$\begin{array}{c}\text { Percentage } \\
10.3\end{array}$} \\
\hline \multirow{7}{*}{ Low-rise building } & $1-10$ & 5.5 & 6 & \\
\hline & $11-20$ & $15 \cdot 5$ & 20 & 34.5 \\
\hline & $21-30$ & 25.5 & 11 & 19.0 \\
\hline & $31-40$ & 35.5 & 4 & 6.9 \\
\hline & 41and a & ve 41.0 & 17 & $29 \cdot 3$ \\
\hline & \multicolumn{2}{|c|}{ Total } & 58 & 100.0 \\
\hline & \multicolumn{2}{|c|}{ Mean $=\mathbf{2 5 . 2 2}$} & & \\
\hline \multirow{7}{*}{ High-rise building } & $1-4$ & 2.5 & 18 & 31.0 \\
\hline & $5-10$ & 7.5 & 7 & 12.1 \\
\hline & $11-20$ & 15.5 & 17 & 29.3 \\
\hline & $21-30$ & 25.5 & 4 & 6.9 \\
\hline & 31 and & ve 31.0 & 12 & 20.7 \\
\hline & \multicolumn{2}{|c|}{ Total } & 58 & 100.0 \\
\hline & \multicolumn{2}{|c|}{ Mean $=14 \cdot 40$} & & \\
\hline \multirow{7}{*}{ Civil engineering works } & \multicolumn{2}{|c|}{ None } & 10 & 17.2 \\
\hline & $1-5$ & 5.5 & 28 & 48.3 \\
\hline & $6-10$ & 8.0 & 5 & 8.6 \\
\hline & $11-20$ & 15.5 & 9 & 15.5 \\
\hline & 21 and & ve 21.0 & 6 & 10.3 \\
\hline & \multicolumn{2}{|c|}{ Total } & 58 & 100.0 \\
\hline & \multicolumn{2}{|c|}{ Mean $=7.92$} & & \\
\hline \multirow{6}{*}{ Industrial engineering works } & \multicolumn{2}{|c|}{ None } & 31 & 53.4 \\
\hline & $1-5$ & 3.0 & 15 & 25.9 \\
\hline & $6-10$ & 8.0 & 6 & 10.3 \\
\hline & $11-20$ & 15.5 & 3 & 5.2 \\
\hline & 21 and & ve 21.0 & 3 & 5.2 \\
\hline & Mea & 3.49 & 58 & 100.0 \\
\hline
\end{tabular}

Source: Authors' field work (2013).

Table 4: Nature and size of projects handled by quantity surveying firms since inception

carried out on core skills requirement and competencies expected of quantity surveyors, classified fourteen skills as basic. The preferred basic skills included the following: information technology, civil/heavy engineering, mechanical and electrical services engineering, gas petrochemical engineering, solid mineral engineering, marketing/business skills, leadership skills, managerial skills, interpersonal skills and communication skills (Dada and Jagboro, 2012). Others are: actuarial skills, knowledge about international trading and investment analysis. These are all regarded as essential requirements needed by quantity surveyors to be able to perform his duty.

According to Dada and Jagboro (2012) in Table 3, the following were categorized as future areas or skills to be explored: Knowledge about international trading, investment analysis and solid mineral engineering because they were least rated. The implication is that these skills were considered less important for quantity surveyors (Dada and Jagboro, 2012). The results of the ANOVA carried out (at Sig. $15 \%$ ) showed significant difference in the opinion among the groups of respondents emanating from 10 competency areas in Civil/Heavy Engineering, Gas/ Petrochemical Engineering, Solid mineral Engineering, Measurement/ Quantification, Economics, Marketing/ Business Skill and Leadership Skill among others. This may be due to the fact that some of the respondents 
might think that anything that have to do with engineering and business skill may not be necessary for quantity surveyors. The results of the overall mean ranking, however, proved otherwise this assumed notion [Dada and Jagboro, 2012; Nkado, 2000). In essence, quantity surveyors are expected to perform and compete favorably well not only on building construction projects but also civil/heavy (industrial) engineering projects as they have skills and are competent in these areas not minding the perception/notion of the public or restriction from other allied professionals like Engineers among others.

\section{Research Methodology}

The essence of this study is to assess the nature of projects undertaken by Quantity Surveyors in Lagos state and structured questionnaire was designed, census method was used and 58 Senior / Associate partners of Quantity Surveying consultancy firms responded to the questionnaire out of 74 firms. This represents $78 \%$ of the total population of QSF in Lagos state as at January, 2012 according to NIQS. The choice of Lagos State is on the premise that Lagos is the commercial nerve-centre of Nigeria, the major hub of construction activities and the fact that majority of the companies have their national headquarters in Lagos, Nigeria (Oyediran and Akintola, 2011; Babatunde et al., 2010).

\section{Research rigour}

Researches can be classified into positivist or the interpretative paradigm or philosophy and if a research reflects the principles of positivism, then it has taken the stance that there is a reality out there waiting to be discovered and this reality could be measured and assessed objectively (Wong et al, 2012). This research has adopted the positivism paradigm by assessing nature of projects undertaken by quantity surveyors in Lagos state, Nigerian when compared with the areas of competencies of quantity surveyors. Rigour which ensures that scientific results stems from standard and accurate means in research McGregor and Murnane (2010) needs to be established (Darke et al., 1998). Adedokun, Ibironke and Olanipekun (2013) relate rigour to legitimizing research process; where validity and reliability are the tests of rigour in positivist (quantitative) research. Wong et al. (2012) added a third criterion (sensitivity) to validity and reliability as means of ensuring good measuring instrument. Sensitivity is the ability of research instrument to capture the variability in responses and 5-point likert scale was advocated because it allows for optimum choice of response (Adedokun et al., 2013); and thus was adopted in this study.
Data collection instrument; method of data presentation and analyses The research instrument used for collecting data from the respondents was a structured questionnaire. It was administered using a set of predetermined questions. The questions designed were such that first section dwelt on the demographics of the respondents while the other section focused on matters relating to the study. Questions inherent in the structured questionnaire were multiple-choice type with different checkboxes to ensure that responses were on the same basis, thus eliminating bias. Tables were employed for data presentations while the analyses were carried out using percentile and mean. Percentile was used for analyzing the range of projects undertaken, number of respondents, and the profile of the firm, while mean was adopted to establish the average number of projects undertaken and age of the firm in terms of existence/ establishment among others.

\section{Results And Discussions}

\section{Introduction}

Out of 74 Quantity Surveying firms in Lagos state, that are duly registered with National Institute of Quantity Surveyors, as at January, 2012, 58 number representing $78 \%$ responded to the questionnaire and

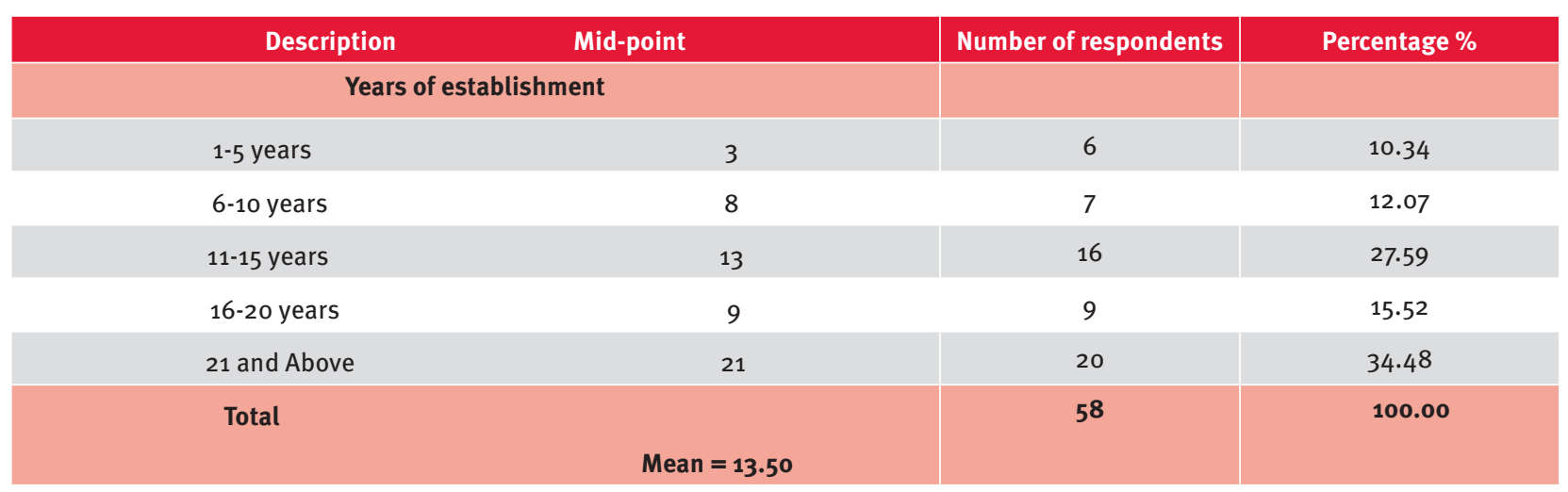

Source: Authors' field work (2013).

Table 5: Profile of the quantity surveying firms 
the percentage is considered adequate for analysis as this is far greater than $30 \%$ minimum deemed to be adequate (Babatunde, 2012; Moser and Kalton, 1999). Senior/ Associate partners of the firms responded to the questionnaire accordingly.

Table 4 indicates that $34.5 \%$ have handled 11-20 low-rise building projects since inception, $29.3 \%$ also handled above 40 types of such projects. When it comes to high-rise building, $31 \%$ handled $1-4,29.3 \%$ of the firms executed 11-20 since inception, while only $20.7 \%$ handled above 30 high-rise buildings since inception of their firms.

As for civil engineering works, about half $(48.3 \%)$ of the firms handled $1-5$ projects since inception, $17.2 \%$ of the firms never handled civil engineering projects at all, while only $10.3 \%$ handled more than 20 civil engineering works since the establishment of the firm. When it comes to industrial engineering works, more than half (53.4\%) never handled such work at all, $25.9 \%$ handled $1-5$ projects in this category, while only $5.2 \%$ handled $11-20$ and above 20 industrial engineering works respectively. In summary, on the average of 14 years of establishing these quantity surveying firms, they only handled 25 low-rise building, 14 high-rise building while they were only involved in 8 civil engineering works and 3 industrial engineering works (Tables 4 \& 5) and this closely related to the work of Said et al. (2010) that quantity surveying educators and practices alike, are still deeply entrenched in the 'traditional' core competencies rather than the newer and more novel services and skills.

Table 5 indicates that $34.48 \%$ of the firms where respondents worked have been in existence for more than 20 years of establishment (i.e 21 and above). Next are those firms that have been existence between 11 and 15 years that constitute $27.59 \%$, while those between $16-20$ years are $15.52 \%$. In a nutshell, those that have been in existence for 11 years and above constitute more than three-quarter (77.59) of the respondents which shows that the firms should have enough experience. On the whole, they all have average of 14 years of existence.

\section{Conclusion And}

\section{Recommendation}

In order to enhance effectiveness, discourage usurpation of roles among the professionals and increasing cost of construction works coupled with insistent collapse of buildings, the study assessed nature of projects undertaken by quantity surveying firms taking into consideration the provisions of RICS, it is hereby concluded that:

Majority of quantity surveying firms limit their area of operations to building works and some of them handled few civil engineering works while only very few of them delved into industrial engineering works, thereby leaving their substantial role in engineering works to be performed by others alongside theirs.

Based on this finding, the proposed policy recommendation is that the management of quantity surveying firms should delve into civil and industrial engineering works as a result of the opportunities that abound in these areas. It will also ensure cost effectiveness of these projects since the areas fall within quantity surveyors competencies jurisdictions.

\section{References}

Adedokun, O.A., Ibironke, O.T. and Olanipekun, A.O. (2013), "Vulnerability of Motivation Schemes in Enhancing Site Workers Productivity for Construction Industry's Sustainability in Nigeria”, International Journal of Sustainable Construction Engineering \& Technology, Vol. 4 No. 1, pp. 22-31.

Ameh, O.J. and Odusami, K.T. (2002), "Factors Affecting Labour Productivity in the Nigerian Construction Industry - A Case Study of Indigenous Contracting Organization in Lagos”, The Quantity Surveyor, Vol. 40 No. 3, pp. 14-18.

Andawei, M.M. and Nyenke, K.N.O. (2001), "Economic Imperative of Project Management Concept in Construction Industry: A Case Study of Selected Companies in Nigeria", The Quantity Surveyor, Vol. 37 No. 4, pp. 13-17.

Babatunde, S.O. (2012), "Susceptibility of building elements to variation in Construction Projects in Nigeria", an M.Sc Thesis submitted to the Faculty of Environmental Design and Management, Obafemi Awolowo University, Ile-Ife, Nigeria.

Babatunde, S.O., Opawole, A. and Ujaddughe, I.C. (2010), “An appraisal of project procurement methods in the Nigerian construction industry", Civil Engineering Dimension, Vol. 12 No. 1, pp. 1-7.

Dada, J.O. and Jagboro, G.O. (2012), “Core skills requirement and competencies expected of quantity surveyors: perspectives from quantity surveyors, allied professionals and clients in Nigeria", Australasian Journal of Construction Economics and Building, Vol. 12 No. 4, pp. 78-90.

Darke, P., Graeme, S. and Broadbent, M. (1998), "Successfully completing case study research: combining rigour, relevance and pragmatism", Information System Journal, Vol. 8, pp. 273-289.

McGregor, S.L.T. and Murnane, J.A. (2010), “Paradigm, methodology and method: Intellectual integrity in consumer scholarship", International Journal of Consumer Studies, Vol. 34 No. 4, pp. 419-427.

Moser, C.A. and Kalton, G. (1999), "Survey Methods in social investigation", (2nd ed), Aldershot, Gower publishing company, pp. 256-269. 
Nigerian Institute of Quantity Surveyors (2004),

"Who is a quantity surveyor? What can he

do for you", Programme of the 21st biennial

conference/general meeting on Adding value

to a reforming economy - Challenge for the

quantity surveying profession in Nigeria, the

Nigerian Institute of Quantity Surveyors.

Nkado, R.N. (2000), “Competencies of

Professional Quantity Surveyors in a

Developing Economy”, available at http://

citeseerx.ist.psu.edu/viewdoc/download?

doi=10.1.1.199.1152\&rep=rep1\&type=pdf,

accessed 9th May, 2014.

Oke, A.E. and Ogunsemi, D.R. (2009),

"Competencies of quantity surveyors as

value manager in a developing economy",

RICS COBRA Research Conference, University

of Cape Town, 10-11th September, 2009, pp

23-38.

Onwusonye, S.I.J. (2002), “The Role of client's

In-House professionals in Capital Project

Procurement and Delivery”, The Quantity

Surveyor, Vol. 38 No. 1, pp. 7-13.

Oyediran, O.S. and Akintola, A.A. (2011), "Survey of the state of the art of $\mathrm{e}$ - tendering in

Nigeria”, Journal of Information Technology

in Construction (ITcon), Vol. 16, pp. 557-576.

Royal Institution of Chartered Surveyors (1998),

“The APC Requirements \& Competencies",

London: Royal Institution of Chartered

Surveyors, London.

Said, I., Shafiel., M.W.M., and Omran, A. (2010), “The competency requirements for Quantity Surveyors: Enhancing Continous Professional Development", available at http://acta.fih. upt.ro/pdf/2010-3/ACTA-2010-3-16.pdf, 2010, accessed 9th May, 2014.

Udeh, M.B.C. (2002), “Improving Relationship between Consultants/Professionals in Construction Industry for Better Services", The Quantity Surveyor, Vol. 40 No. 3, pp. 34-37.

Wikipedia (2014), “Quantity Surveyor”, available at http://en.wikipedia.org/wiki/Quantity_ surveyor, accessed 24th May, 2014.

Wong, K., Ong, S. and Kuek, T. (2012), “Constructing a Survey Questionnaire to Collect Data on Service Quality of Business Academics", European Journal of Social Sciences, Vol. 29 No. 2, pp. 209-221. 